\title{
Bovine Serum Albumin Metal Complexes for Mimic of SOD
}

\author{
GUIFANG YAN, YUFENG HE*, GANG LI, YUBING XIONG, PENGFEI SONG and \\ RONG-MIN WANG* \\ Key Lab. Eco-Environment-Related Polymer Materials of Ministry of Education, Key Lab. Polymer Materials \\ of Gansu Province, College of Chemistry \& Chemical Engineering, Northwest Normal University, Lanzhou \\ 730070, China \\ e-mail: heyufeng@nwnu.edu.cn; wangrm@nwnu.edu.cn
}

MS received 1 June 2016; revised 16 July 2016; accepted 22 August 2016

\begin{abstract}
Superoxide anion radical $\left(\mathrm{O}_{2}^{\bullet-}\right)$ is a noxious reactive oxygen species (ROS). Transition metal ion complexes have been generally used as antioxidants to eliminate ROS. In this work, a neoteric watersoluble biopolymer metal complex (BSA-M) was prepared by conjugating the soluble biopolymer bovine serum albumin (BSA) with three transition metal ions $(\mathrm{M}, \mathrm{M}=\mathrm{Cu}, \mathrm{Co}, \mathrm{Mn})$. The binding mode and ratio of metal ions bound to albumin were investigated. The BSA-M complexes were characterized by UV-Vis, circular dichroism (CD) spectra and polyacrylamide gel electrophoresis (PAGE). BSA served as polymer scaffold and the metal complex functioned as the catalytic active center. The results demonstrated that the structure of BSA remained unchanged when the binding ratio of transition metal ion complex to BSA was $5: 1$. Furthermore, the scavenging superoxide anion free radical $\left(\mathrm{O}_{2}^{\bullet-}\right)$ activity of biopolymer-metal complexes were determined by nitroblue tetrazolium light reduction assay method. The antioxidant capacity of BSA-M has markedly increased. The conjugated BSA-M $(\mathrm{M}=\mathrm{Cu}, \mathrm{Mn})$ showed preeminent scavenging activity for $\mathrm{O}_{2}^{\bullet-}$, and the $\mathrm{EC}_{50}$ value of the BSA-Cu was $0.038 \pm 0.0013 \mu \mathrm{mol} \cdot \mathrm{L}^{-1}$, which is comparable to $\mathrm{EC}_{50}$ value $\left(0.041 \pm 0.001 \mu \mathrm{mol} \cdot \mathrm{L}^{-1}\right)$ of the natural superoxide dismutase (SOD), the analog quantity reached $107 \%$. As a consequence, it can be considered as a bio-functional mimic of enzyme SOD and has a promising application prospect in antioxidant drug field.
\end{abstract}

Keywords. Bovine serum albumin; biopolymer metal complexes; superoxide; free radical; scavenging activity.

\section{Introduction}

Reactive oxygen species (ROS), natural byproducts of the metabolites in human bodies, have four existing forms, namely, hydroxyl radical $(\cdot \mathrm{OH})$, superoxide anion radical $\left(\mathrm{O}_{2}^{\bullet-}\right)$, singlet oxygen $\left(\mathrm{O}_{2}\right)$ and hydrogen peroxide $\left(\mathrm{H}_{2} \mathrm{O}_{2}\right)$. The production of excessive $\mathrm{O}_{2}^{--}$ can lead to oxidative stress and cause tissue damage. Several diseases, such as cancer, ${ }^{1,2}$ inflammation, ${ }^{3}$ cardiovascular disorders, ${ }^{4}$ rheumatoid arthritis ${ }^{5}$ and neuro-degeneration ${ }^{6}$ have been shown to be related to excessive generation of ROS in the physiological system. Excessive ROS can also cause damage to DNA, proteins, and cell membrane lipids, ${ }^{7}$ besides, it can affect the basic functions of cells as well. Copper, zinc superoxide dismutase $(\mathrm{Cu}, \mathrm{Zn}-\mathrm{SOD})^{8}$ is a ubiquitous enzyme which plays an essential role in antioxidant defense by catalyzing the dismutation of $\mathrm{O}_{2}^{\bullet-}$ to oxygen and hydrogen peroxide under physiological conditions. ${ }^{9}$ SOD is found in many organisms, yet

*For correspondence there are still some shortcomings in wide-ranging clinical application of SOD. ${ }^{10}$ Therefore, special attention is paid to the artificial mimics of SOD. Developing highly efficient and stable SOD mimics is the one of the crucial projects in biological chemistry. ${ }^{11}$ To further understand structural factors of the highly efficient superoxide dismutation mechanism, ${ }^{12}$ a majority of mimics for $\mathrm{Cu}, \mathrm{Zn}$-SOD have been reported. ${ }^{13} \mathrm{In}$ the last decades, work on SOD mimic have mostly focused on the enzyme activity center which is the basis of metalloporphyrins, ${ }^{14}$ quasi-porphyrin metal complexes ${ }^{15}$ and Schiff base complexes. ${ }^{16}$ Besides, SOD mimics based on macromolecular compounds like protein, ${ }^{17}$ peptides ${ }^{18}$ synthetic polymers, etc., are reported. However, the SOD-like activities of almost all mimics are extremely low. To our knowledge, of the reported mimics, the highest SOD-like activity is only $20 \%$ of the bovine erythrocyte $\mathrm{Cu}, \mathrm{Zn}-\mathrm{SOD} .{ }^{19}$

It is generally known that the serum albumins are the major dissoluble proteins in the circulatory system. ${ }^{20}$ The most outstanding property of albumins is the ability to bind reversibly to endogenous and exogenous 
complexes. ${ }^{21}$ Bovine serum albumin (BSA) has been chosen as a model protein in the study to bind with small molecule. ${ }^{22}$ It is found that the antioxidative activity of amino acid Schiff base compounds can be strengthened after combining with BSA. ${ }^{23}$ In this paper, transition metal ions are bound to BSA, affording the biopolymer metal complexes (BSA-M), whose activities of scavenging $\mathrm{O}_{2}^{\bullet-}$ were investigated thereafter.

\section{Experimental}

\subsection{Reagents and Instrumentation}

Bovine serum albumin (BSA) was purchased from Shanghai Bio Life Sci. Techn. Co. Ltd. Nature SOD (>90\%) was purchased from Shanghai Yuhua Life Science \& Technology Development Co. Ltd. $\mathrm{Co}(\mathrm{OAc})_{2}$. $4 \mathrm{H}_{2} \mathrm{O}$ and $\mathrm{Cu}(\mathrm{OAc})_{2} \cdot \mathrm{H}_{2} \mathrm{O}$ were obtained from Tianjin Kaitong Chemical Reagent Co. Ltd. $\mathrm{Mn}(\mathrm{OAc})_{2} \cdot 4 \mathrm{H}_{2} \mathrm{O}$ was purchased from Xi'an Chemical Reagent Factory. BSA solutions were prepared in buffer solution ( $\mathrm{pH}=7.4)$ with $0.03 \mathrm{~mol} \mathrm{~L}^{-1} \quad \mathrm{Na}_{2} \mathrm{HPO}_{4} \cdot 12 \mathrm{H}_{2} \mathrm{O}$ and $\mathrm{NaH}_{2} \mathrm{PO}_{4} \cdot 2 \mathrm{H}_{2} \mathrm{O}$. Other chemicals were analytical reagent grade and used without further purification. Double-distilled water was used throughout.

UV-Vis, CD spectra were recorded in solutions at $\mathrm{pH}=7.4$ and $25 \pm 0.1{ }^{\circ} \mathrm{C}$ using an Agilent 8453 spectrophotometer with an Agilent temperature control unit, and Jasco J-810 spectropolarimeter $(1 \mathrm{~cm}$ cell), respectively. NATIVE polyacrylamide gel electrophoresis (NATIVE-PAGE) analysis was performed via DYY12C Electrophoresis apparatus on $8 \%$ polyacrylamide with 5\% stacking. Before loading, different volumes of samples and loading buffer ( $0.5 \mathrm{~mol}$ Tris ( $\mathrm{pH}$ 6.8), $5 \mathrm{~mL}$ glycerol, $0.5 \mathrm{~mL} 0.2 \%$ bromophenol blue and $1.4 \mathrm{~mL}$ distilled water) were mixed.

\subsection{Preparation of bovine serum albumin-metal complexes (BSA-M)}

Firstly, BSA solution $\left(1 \mathrm{mmol} \mathrm{L}^{-1}\right)$ was prepared in a phosphate buffer solution (PBS, $30 \mathrm{mmol} \mathrm{L}^{-1}$ ) and three kinds of metal salts solutions $\left(25 \mathrm{mmol} \mathrm{L}^{-1}\right)$ were prepared in double-distilled water. Secondly, BSA$\mathrm{Cu}$ was prepared as follows: In $5.0 \mathrm{~mL}$ of water, $2.5 \mathrm{~mL}$ of PBS $\left(30 \mathrm{mmol} \mathrm{L}^{-1}\right), 0.5 \mathrm{~mL}$ of BSA solution $\left(1 \mathrm{mmol} \mathrm{L}^{-1}\right)$ and $0.1 \mathrm{~mL}$ of $\mathrm{Cu}(\mathrm{OAc})_{2}\left(25 \mathrm{mmol} \mathrm{L}^{-1}\right)$ were mixed and incubated for $4 \mathrm{~h}$ with stirring at room temperature in darkness. In the obtained BSA-Cu solution, the concentration of BSA was calculated based on the final volume of the solution.
The preparations of BSA-Mn and BSA-Co were analogous to BSA-Cu.

\subsection{Scavenging activity of superoxide anion radical}

The scavenging activity of superoxide anion radicals was assayed via the inhibition of nitroblue tetrazolium (NBT) light reduction method. ${ }^{24}$ It is an indirect method, in which the superoxide anion radicals $\left(\mathrm{O}_{2}^{\bullet-}\right)$ produced by riboflavin upon illumination of light inhibit the reduction of NBT. The development of blue color was monitored at $560 \mathrm{~nm}$ using UV-Vis spectra (in phosphate buffer), and the inhibition rate ( $\mathrm{F} \%)$ of $\mathrm{O}_{2}^{\circ-}$ was calculated according to Eq. 1.

$$
\mathrm{F}(\%)=\left(1-\Delta / \Delta_{0}\right) \times 100 \%
$$

where, $\Delta$ and $\Delta_{0}$ are the absorbances in the presence and absence, respectively, of the measured compound. The total volume of reaction mixture was $3.0 \mathrm{~mL}$, which included potassium phosphate buffer solution $(0.05 \mathrm{~mol}$ $\left.\mathrm{L}^{-1}, \mathrm{pH} 7.8\right)$, NBT $\left(4.66 \times 10^{-5} \mathrm{~mol} \mathrm{~L}^{-1}\right)$, riboflavin $\left(3.4 \times 10^{-6} \mathrm{~mol} \mathrm{~L}^{-1}\right)$ and methionine $\left(0.01 \mathrm{~mol} \mathrm{~L}^{-1}\right)$. The action mixture was saturated under $25^{\circ} \mathrm{C}$ for $0.5 \mathrm{~h}$. In testing, the reaction mixture and different quantities of antioxidant were illuminated with light whose intensity was $4000( \pm 100)$ Lux, and the absorbance of the reaction mixture at $560 \mathrm{~nm}$ was assayed (time interval was $30 \mathrm{~s}$ ). The SOD-like activity of the studied compounds was compared with native $\mathrm{Cu}-\mathrm{SOD}$.

\section{Results and Discussion}

Proteins are well-known for efficiency and selectivity that few other natural or artificial molecules can match, ${ }^{24,25}$ whether in catalysis or molecular recognition. Owing to 35 cysteine residues, human serum albumin (HSA) is facile to be combined with metal ions. The serum albumin is readily available, non-antigenic and biodegradable; it has been used in biomedical applications, such as neoteric hydrophilic and drug delivery carriers. ${ }^{26}$ In our previous investigations, it was discovered that albumin integrated with zinc-protoporphyrin IX, which can be applied in photosensitized reduction of water to $\mathrm{H}_{2} \cdot{ }^{27}$ Although antioxidative capacity of BSA was fairly weak, ${ }^{28}$ it can be dramatically improved after combining with amino acid Schiff base compounds. ${ }^{29}$

Based on the fact that BSA is a natural polymer, great efforts have been made to investigate the $\mathrm{O}_{2}^{--}$scavenging using BSA-M as antioxidant. Transition metal ions $\left(\mathrm{Cu}^{\mathrm{II}}, \mathrm{Mn}^{\mathrm{II}}, \mathrm{Co}^{\mathrm{II}}\right)$ were combined into $\mathrm{BSA}$, which 
afforded bovine serum albumin metal complexes (BSAM). BSA-M was characterized by UV spectra, CD spectra, Gel electrophoresis analysis, Zeta potential, particle size analysis, NATIVE-PAGE and SDS-PAGE. The results demonstrated that the structure of BSA was maintained when the binding ratio $\left(\mathrm{n}_{\mathrm{M}}: \mathrm{n}_{\mathrm{BSA}}\right)$ of BSA-M was 5:1, and BSA-M indicated good antioxidant activity.

\subsection{UV spectra}

The BSA metal complexes were characterized by UV spectra (Figure 1). In BSA, the characteristic absorption peak appearing at $278 \mathrm{~nm}$ is assigned to amino acid (e.g., tryptophan). ${ }^{30}$ The characteristic peak is maintained in BSA-M. However, the absorption peak decreased, especially in BSA-Cu and BSA-Co.

\subsection{CD spectra}

Circular Dichroism (CD) spectroscopy was used to monitor the interaction of metal ions with BSA. BSA has a high percentage of $\alpha$-helical structure which exhibited two negative bands in the ultraviolet region, ${ }^{31}$ while metal ions do not show any $\mathrm{CD}$ signal in this region. The interaction and binding of BSA with $\mathrm{M}$ could be assessed as follows. The ellipticity of BSA changed after interacting with molecule; ${ }^{32}$ BSA showed negative absorption signal with maximum at around $222 \mathrm{~nm}$ and $208 \mathrm{~nm} .{ }^{33}$ Compared with BSA, the intensity of the characteristic CD signal in BSA-M did not decrease (Figure 2). It indicates that the secondary

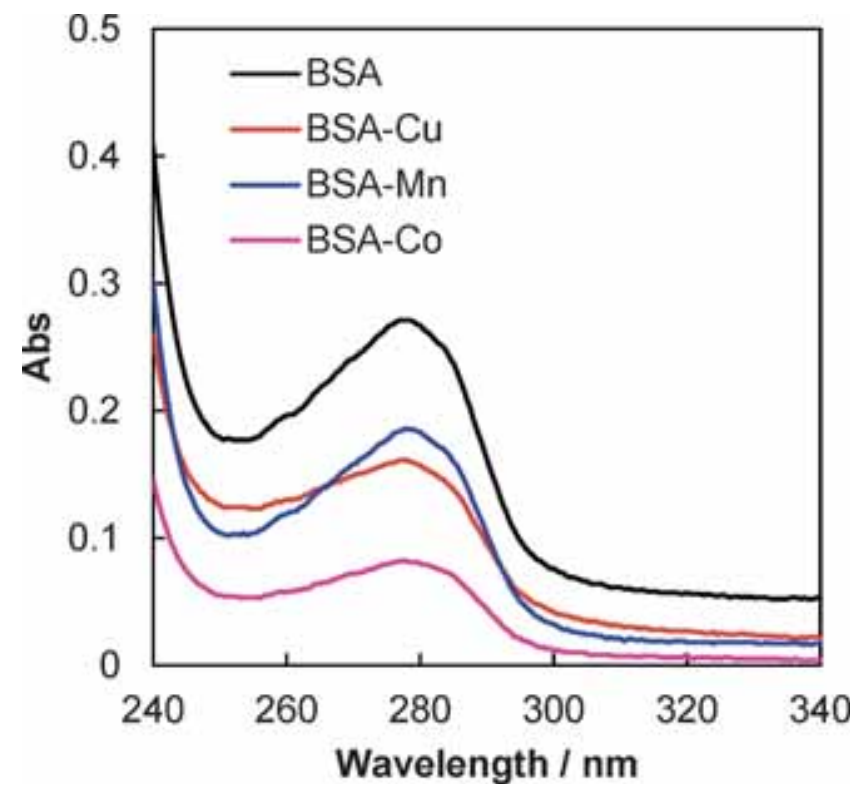

Figure 1. UV-Vis absorption spectra of BSA, BSA-M $(\mathrm{M}=\mathrm{Cu}, \mathrm{Mn}, \mathrm{Co})$ in $\mathrm{pH}$ 7.4 PBS ([BSA]: $\left.2 \times 10^{-7} \mathrm{~mol} \mathrm{~L}^{-1}\right)$. structure of BSA is still maintained when transition metal ions bind to BSA. In other words, metal ions binding to BSA make a slight change in the secondary structure of BSA. The $\alpha$-helical content of BSA in presence of the transition metals can be calculated from the CD results (Table 1). The $\alpha$-helical content of BSA is $56 \%$, and it slightly decreases after binding with transition metal ions.

\subsection{Zeta potential and particle size analysis}

Zeta potential indicates the surface charge property of the solid particles in the solution. Zeta potential and particle size of BSA-M were analyzed by dynamic light scattering and results are summarized in Table 2. Compared with BSA, particle sizes of BSA-M increased. It is considered that the original closed structure of BSA became loose after binding with metal ions, which caused particle size of the BSA-M complex to change.

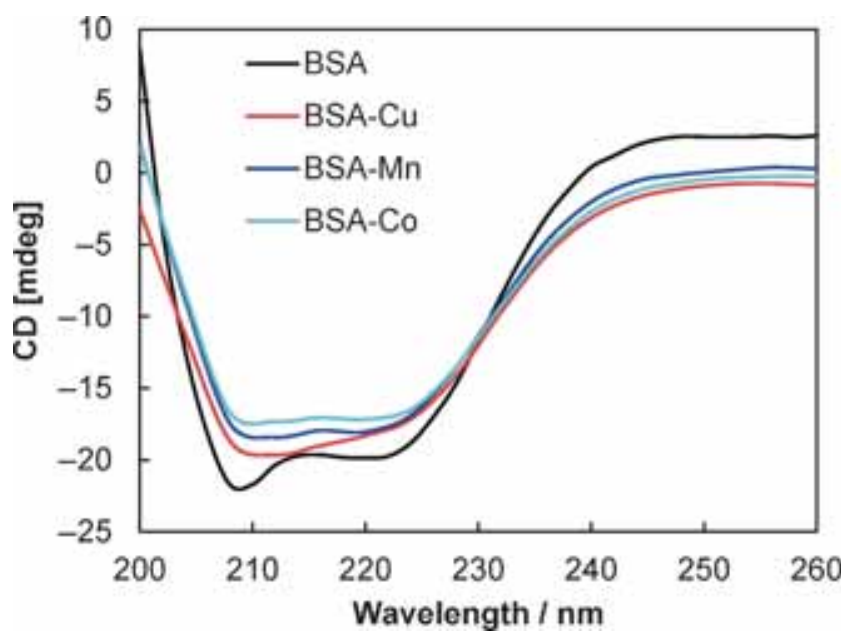

Figure 2. $\mathrm{CD}$ spectra of $\mathrm{BSA}, \mathrm{BSA}-\mathrm{M}(\mathrm{M}=\mathrm{Cu}, \mathrm{Mn}, \mathrm{Co})$ in $\mathrm{pH} 7.4 \mathrm{PBS}$ ([BSA]: $2 \times 10^{-7} \mathrm{~mol} \mathrm{~L}^{-1}$, pathlength: $\left.1 \mathrm{~cm}\right)$.

Table 1. The $\alpha$-helical content of BSA in BSA-M.

\begin{tabular}{lc}
\hline Compound & $\alpha-$ helical \% \\
\hline BSA & 56 \\
BSA-Cu & 51 \\
BSA-Mn & 52 \\
BSA-Co & 44 \\
\hline
\end{tabular}

Table 2. The particle size and zeta potential of BSA-M.

\begin{tabular}{lcr}
\hline ROS scavenger & Size $(\mathrm{nm})$ & Zeta $(\mathrm{mV})$ \\
\hline BSA & 7.80 & -12.91 \\
BSA-Cu & 9.10 & -9.31 \\
BSA-Mn & 10.18 & -15.16 \\
BSA-Co & 11.14 & -11.80 \\
\hline
\end{tabular}


Since protein contains a large number of functional groups, such as amino group, carboxyl group, etc., protein can form complexes with metal ions, and result in the changes of surface charge. ${ }^{34}$ It is noticeable that the zeta potentials of BSA and BSA-M are different.

\subsection{Gel Electrophoresis Analysis}

The Polyacrylamide Gel Electrophoresis (PAGE) was used to measure the variations of macromolecular weight (Figure 3). The chart of Native-PAGE of BSA-M and BSA are exhibited in Figure 3A, and sodium dodecyl sulfate PAGE (SDS-PAGE) is shown in Figure 3B. It shows that there is a slight change of molecular weight of BSA after combining with the metal ions. The electrophoresis bands of BSA-M $(\mathrm{M}=\mathrm{Cu}, \mathrm{Mn}, \mathrm{Co})$ are almost the same as that of BSA. Although the local charge density of BSA may change after combining with metal ions, its global charge density is stable.

\subsection{Superoxide Anion Radical $\left(\mathrm{O}_{2}^{\bullet-}\right)$ scavenging ability of $B S A-M$}

Superoxide anion radical $\left(\mathrm{O}_{2}^{\bullet-}\right)$, a noxious ROS is produced by one electron reduction of dioxygen $\left(\mathrm{O}_{2}\right)$. Here, the $\mathrm{O}_{2}^{--}$scavenging is assayed via the inhibition

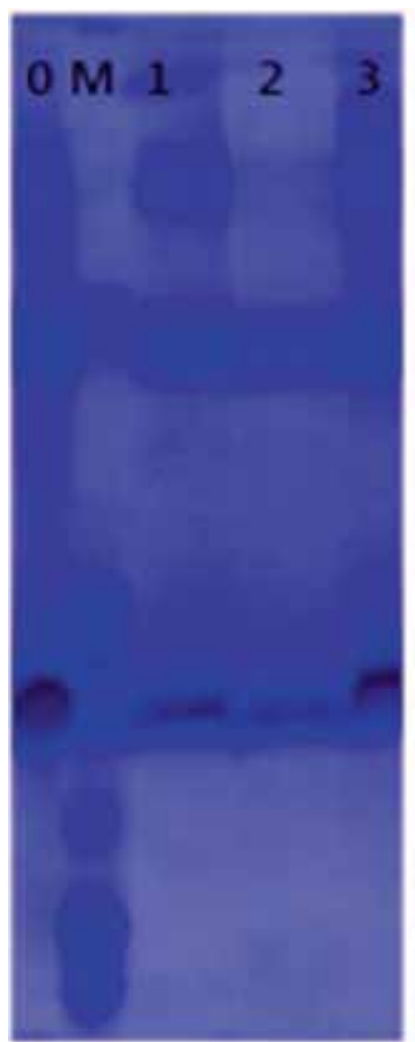

(a)

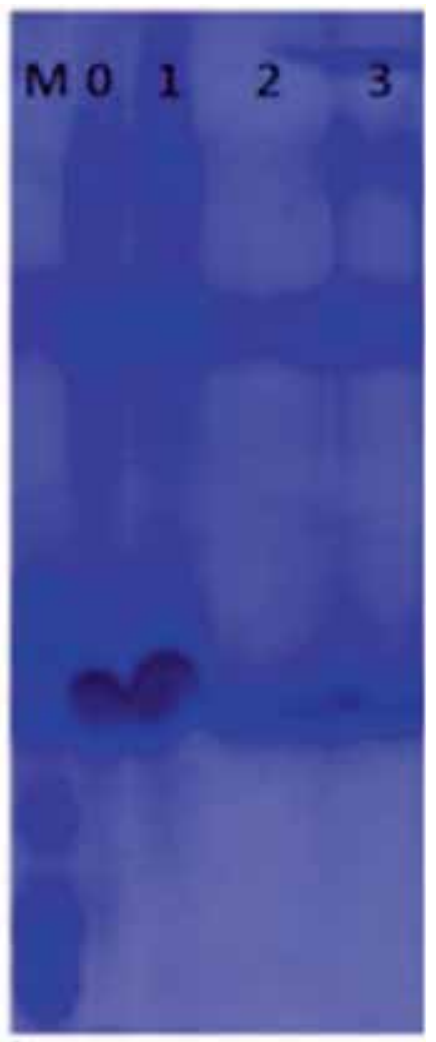

(b)

Figure 3. Native PAGE (A) and SDS-PAGE (B). M: Marker, 0: BSA, 1: BSA-Cu, 2: BSA-Co, 3: BSA-Mn. of nitroblue tetrazolium (NBT) light reduction method, and the formation of blue formazan is monitored at $560 \mathrm{~nm}$ in UV-Vis spectrum.

Median extinction concentration $\left(\mathrm{EC}_{50}\right)$ is the concentration of antioxidant which is required for the stable free radical to be quenched $50 \%$. The $\mathrm{EC}_{50}$ values of BSA and BSA-M are given in Table 3. The $\mathrm{EC}_{50}$ of $\mathrm{BSA}-\mathrm{Cu}$ is $0.038 \pm 0.001 \mu \mathrm{mol} \mathrm{L} \mathrm{L}^{-1}$, which is the lowest of all. The $\mathrm{EC}_{50}$ of natural $\mathrm{SOD}^{35}$ is $0.041 \pm$ $0.001 \mu \mathrm{mol} \mathrm{L}^{-1}$. The $\mathrm{EC}_{50}$ of BSA-Cu reaches $107 \%$ compared with natural $\mathrm{Cu}, \mathrm{Zn}-\mathrm{SOD}$.

Although metal ions show radical scavenging activity, the capacity is relatively weak. However, after binding with BSA, the antioxidant activity is enhanced. The superoxide anion radical scavenging effects of BSA-M $(\mathrm{M}=\mathrm{Cu}, \mathrm{Mn}, \mathrm{Co})$ were investigated for different concentrations (Figure 4). The scavenging activity of different metal ions of BSA-M is as follows: BSA-Cu > BSA-Mn $>$ BSA-Co. Since it is facile for $\mathrm{Cu}^{\mathrm{II}}$ to bind with amino acid residues, the combining proportion of $\mathrm{BSA}$ and $\mathrm{Cu}^{\mathrm{II}}$ is much higher.

Single metal ion also has the ability of scavenging the $\mathrm{O}_{2}^{--}$free radical. ${ }^{36}$ For this reason, the superoxide

Table 3. $\mathrm{EC}_{50}$ of BSA and BSA-M.

\begin{tabular}{lc}
\hline Compound & $\mathrm{EC}_{50}\left(\mu \mathrm{mol} \mathrm{L}{ }^{-1}\right)$ \\
\hline BSA-Cu-5 & $0.038 \pm 0.001$ \\
BSA-Mn-5 & $1.00 \pm 0.07$ \\
BSA-Co-5 & $7.50 \pm 0.15$ \\
BSA & $518.0 \pm 5.60$ \\
\hline
\end{tabular}

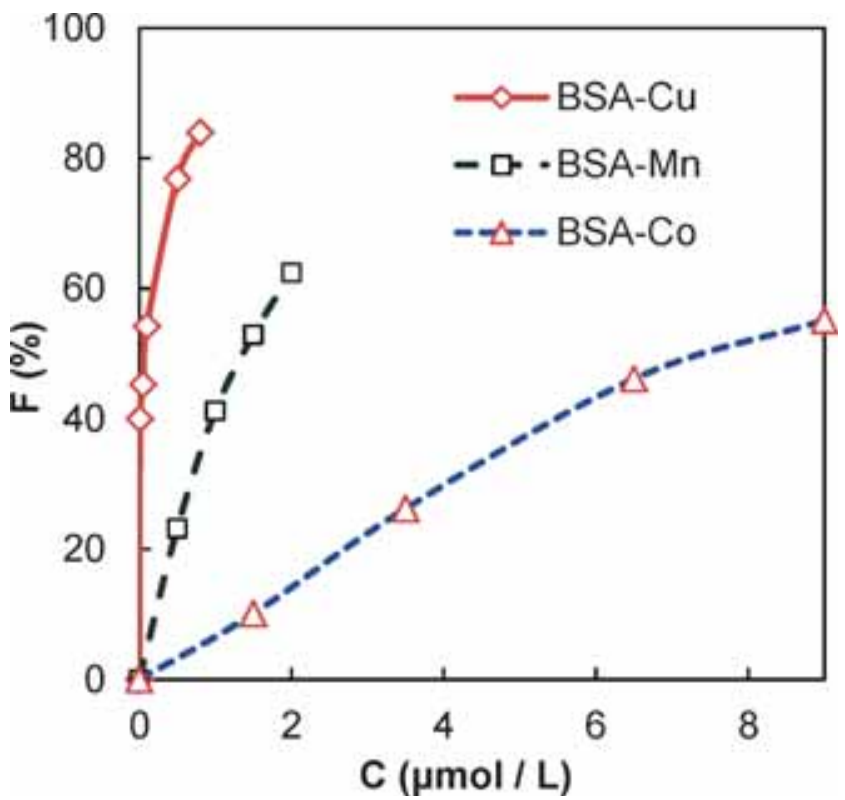

Figure 4. Superoxide anion radical scavenging activity (Scavenging \%) of BSA-M $(\mathrm{M}=\mathrm{Cu}, \mathrm{Mn}, \mathrm{Co})$. 
anion radical scavenging effect of single metal ion was also investigated (see Figure 5 and Figure S1 in Supplementary Information). In summary, although BSA and metal ions are able to scavenge free radicals at high concentrations, the biopolymer metal complexes (BSA-M) display excellent activity for scavenging the free radicals.

\subsection{Active center and mechanism of $\mathrm{O}_{2}^{\bullet-}$ scavenging}

BSA has the capability to scavenge free radicals but it is exceedingly weak. However BSA-M conjugates have

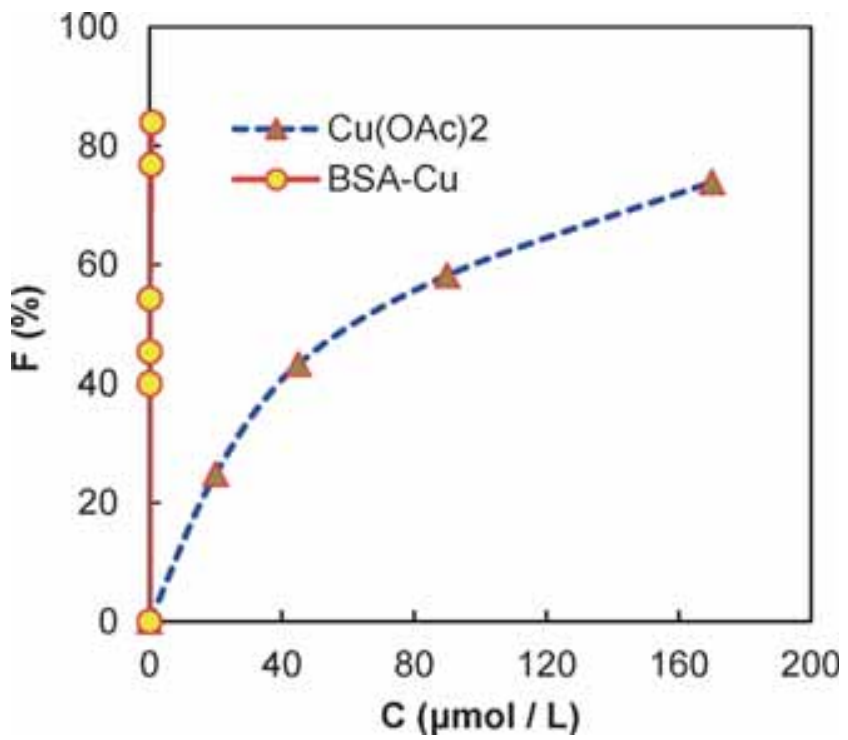

Figure 5. Comparison the superoxide anion radical scavenging activity $(\%)$ of $\mathrm{Cu}^{\mathrm{II}}$ with BSA-Cu.

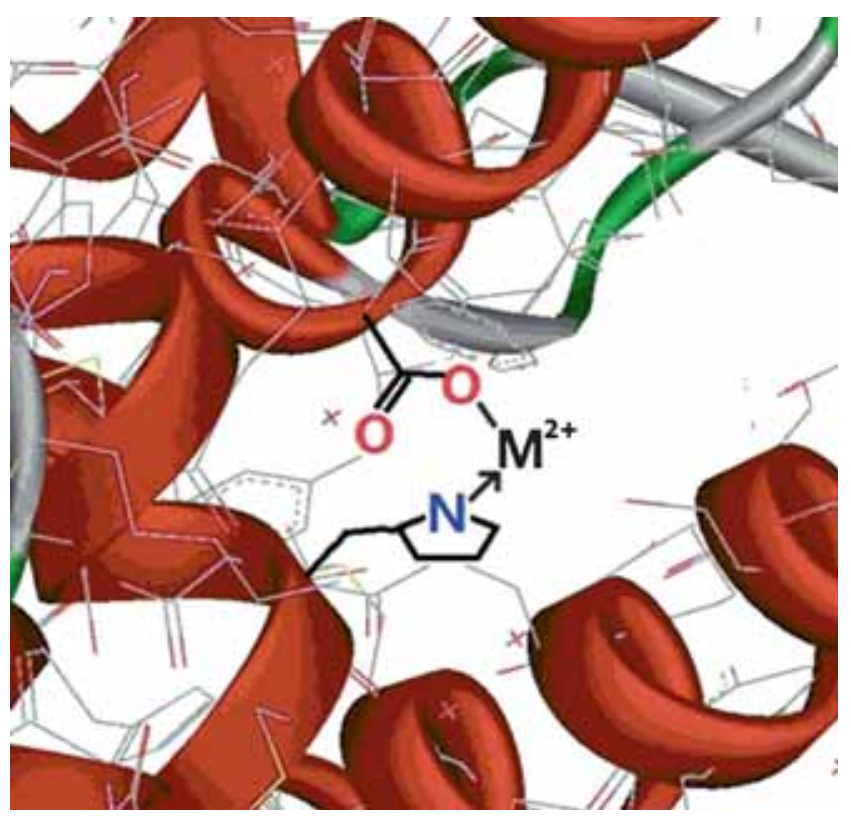

Scheme 1. Active center for $\mathrm{O}_{2}^{\bullet-}$ scavenging of BSA-M.
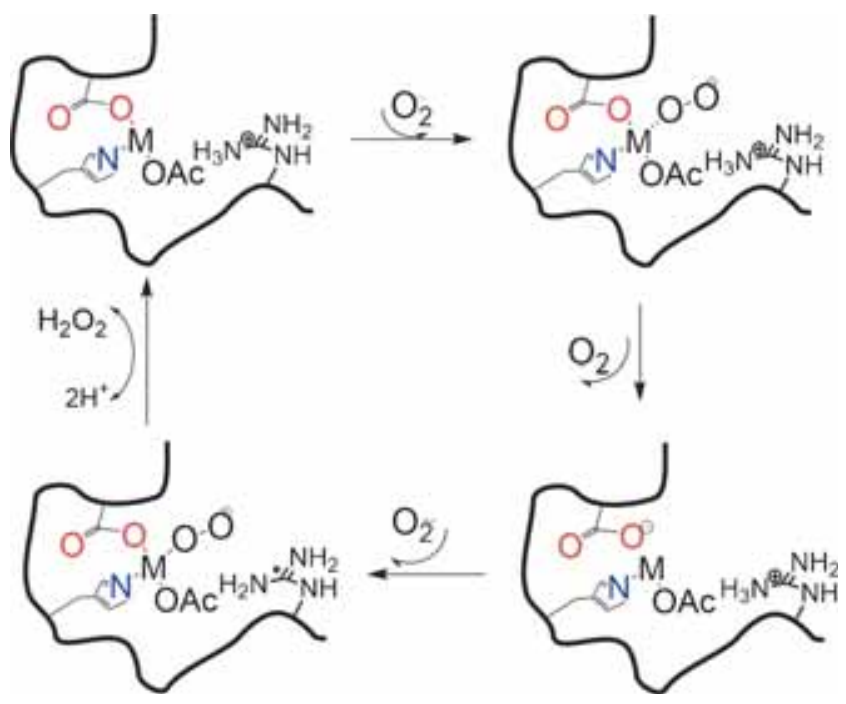

Scheme 2. Mechanism for $\mathrm{O}_{2}^{\bullet-}$ scavenging of BSA-M.

better antioxidant activity at lower $\mathrm{EC}_{50}$. So the metal ion in complexes played a significant part in ROS scavenging. Zhou et al., reported that arginine was indispensable for high superoxide dismutases (SOD) activity which could steer the $\mathrm{O}_{2}^{\bullet-}$ substrate to the metal ion. ${ }^{37}$ According to the reported catalytic mechanism ${ }^{38}$ and our experience, we suggest the the active center of $\mathrm{O}_{2}^{\bullet-}$ scavenging (Scheme 1) and its mechanism (Scheme 2). Besides a feasible mechanism for $\mathrm{O}_{2}^{\bullet-}$ scavenging of BSA-M is suggested as below. Metal ions bound to ligands of amino acid side chain (via nitrogen and oxygen) form a ring of reaction centers. ${ }^{39}$ The synergistic effect of multiple activity centers makes BSA-M complexes to have a higher ability to scavenge $\mathrm{O}_{2}^{\circ-}$.

\section{Conclusions}

A simple biopolymer metal complex (BSA-M) was prepared via BSA binding transition metal ions, where BSA served as scaffold and metal complexes as the catalytic active centers. The antioxidant activity of complex was measured by NBT assay. After binding with metal ions, the scavenging of superoxide anion free radical $\left(\mathrm{O}_{2}^{\bullet-}\right)$ activity of biopolymer metal complexes (BSA-M) obviously increased. The BSA-Cu conjugate exhibited remarkable capacity for scavenging $\mathrm{O}_{2}^{--}$. Therefore, as a biofunctional mimic of antioxidant enzymes, BSA-Cu is an excellent biopolymer oxidant radical scavenger.

\section{Supplementary Information (SI)}

The $\mathrm{O}_{2}^{\bullet-}$ free radical scavenging ability of metal ion $\left(\mathrm{Mn}^{\mathrm{II}}, \mathrm{Zn}^{\mathrm{II}}\right)$ and BSA-Mn and BSA-Zn are shown in 
Figure S1. Supplementary Information is available at www.ias.ac.in/chemsci.

\section{Acknowledgements}

The project was supported by the NSFC (21263024, 21364012) of China and IRTGP (1210RJIA004) for financial support.

\section{References}

1. Guha P, Dey A, Dhyani M V, Sen R, Chatterjee M, Chattopadhyay S and Bandyopadhyay S K 2010 J. Pharmacol. Exp. Ther. 334381

2. Ray P D, Huang B W and Tsuji Y 2012 Cell Signal. 24 981

3. Kang O H, Jang H J, SChae H, Oh Y C, Choi J G, Lee Y S, Kim J H, Kim Y C, Sohn D H, Park H and Kwon D Y 2009 Pharmacol. Res. 59330

4. Das M and Das D K 2010 Mol. Aspects Med. 31503

5. Bai Y, Mao Q Q, Qin J, Zheng X Y, Wang Y B, Yang K, Shen H F and Xie L 2010 Cancer Sci. 101488

6. Iuga C, Alvarez-Idaboy J R and Russo N 2012 J. Org. Chem. 773868

7. Mohaved A, Yu L, Thandapilly S J, Louis X and Netticadan T 2012 Arch. Biochem. Biophys. 52774

8. Seenivasan R, Anantha K K, Kalpana B, Govindaswamy I, Srigiridhar K and Chandran K 2010 Biosens. Bioelectro. 26689

9. Dupeyrat F, Vidaud C, Lorphelin A and Berthomieu C 2004 J. Biol. Chem. 27948091

10. Liochev S I 2013 Free Radical Bio. Med. 601

11. Brittes J, Lucio M, Nunes C and Reis S 2010 Chem. Phys. Lipids 163747

12. Selvaraj S, Krishnaswamy S, Devashya V, Sethuraman S and Krishnan U M 2011 Langmuir 2713374

13. Babita S, Pradip K B and Diganta K D 2015 J. Chem. Sci. 127455

14. Lee J, Hunt J A and Groves J T 1998 J. Am. Chem. Soc. 1207493

15. Cuzzocrea S, Mazzon E, Di Paola R, Genovese T, Mui C, Caputi A P and Salvemini D 2005 Arthritis Rheumatol. 521929

16. Lekha L, Kanmani Raja K, Rajagopal G and Easwaramoorthy D 2014 J. Organomet. Chem. 75372

17. Kim J S, Wilson J M and Lee S R 2010 J. Nutr. Biochem. 21

18. Ibrahim H R, Hoq M I and Aoki T 2007 Int. J. Biol. Macromol. 41631
19. Colak A, Terzi U, Col M, Karaoglu S A, Karabocek S, Kucukdumlu A and Ayaz F A 2010 Eur. J. Med. Chem. 455169

20. Buchtik R, Travnicek Z and Vanco J 2012 J. Inorg. Biochem. 116163

21. Gorudko I V, Grigorieva D V, Shamova E V, Kostevich V A, Sokolov A V, Mikhalchik E V, Cherenkevich S N, Arnhold J and Panasenko O M 2014 Free Radical Bio. Med. 68326

22. Komatsu T, Wang R M, Zunszain P A, Curry S and Tsuchida E 2006 J. Am. Chem. Soc. 12816297

23. Wang R M, Mao J J, Song J F, Huo C X and He Y F 2007 Chin. Chem. Lett. 181416

24. Yin X C, Li X X, Wang R M, Li G and He Y F 2012 Pure Appl. Chem. 842641

25. Ohtsu H, Shimazaki Y, Odani A, Yamauchi O, Mori W, Itoh S and Fukuzumi S $2000 \mathrm{~J}$. Am. Chem. Soc. 122 5733

26. Huang Y, Komatsu T, Wang R M, Nakagawa A and Tsuchida E 2006 Bioconjugate Chem. 17393

27. Komatsu T, Wang R M, Zunszain P A, Curry S and Tsuchida E 2006 J. Am. Chem. Soc. 12816297

28. Moran E C, Kamiguti A S, Cawley J C and Pettitt A R 2002 Brit. J. Haematol. 116316

29. Li G, Zhang H F, Wang R M, He Y F and Xiong Y B 2013 Chin. Sci. Bull. 582956

30. Peters T 1996 In All About Albumin: Biochemistry, Genetics, and Medical Applications, (San Diego CA: Academic Press)

31. Asadi M, Asadi Z, Sadi S B, Zarei L, Baigi F M and Amirghofran Z 2014 Spectrochim. Acta A 122118

32. Rafael S P, Mezger A, Lieb B, Dallinger R, Capdevila M, Palacios O and Atrian S 2012 J. Inorg. Biochem. 108 84

33. Quiming N S, Vergel R B, Nicolas M G and Villsnueva J A 2005 J. Health Sci. 518

34. Zhang A, Huang C, Shi H, Guo W, Zhang X, Xiang H, Jia T, Miao F and Jia N 2016 Sens. Actuators, B-Ch 238 24

35. Xu Z L, Pan S J, Li G, He Y F and Wang R M 2015 J. Inorg. Organomet. Polym. 251313

36. Li X X 2012 In Master's Dissertation: Studies on Antioxidant Functions of Feather Keratin Metal Complexes (Lanzhou: Northwest Normal University)

37. Zhou Y H, Fu H, Zhao W X, Chen W L, Su C Y, Sun H, Ji L N and Mao Z W 2007 Inorg. Chem. 46734

38. Hart P J, Balbirnie M M, Ogihara N L, Nersissian A M, Weiss M S, Valentine J S and Eisenberg D 1999 Biochemistry 382167

39. Shrivastava H Y, Kanthimathi M and Nair B U 1999 Biochem. Bioph. Res. Comm. 265311 